\title{
Cancer stem cells and signaling pathways in radioresistance
}

\author{
Lei Chang ${ }^{1,2}$, Peter Graham ${ }^{1,2}$, Jingli Hao ${ }^{1,2}$, Jie Ni ${ }^{1,2}$, Junli Deng ${ }^{1,2}$, Joseph Bucci ${ }^{1,2}$, \\ David Malouf ${ }^{3}$, David Gillatt ${ }^{3,4}$ and Yong $\mathbf{L i}^{1,2}$ \\ ${ }^{1}$ Cancer Care Centre, St George Hospital, Kogarah, NSW, Australia \\ ${ }^{2}$ St George and Sutherland Clinical School, Faculty of Medicine, University of New South Wales, Kensington, NSW, Australia \\ ${ }^{3}$ Department of Urology, St George Hospital, Kogarah, NSW, Australia \\ ${ }^{4}$ Australian School of Advanced Medicine, Macquarie University, Sydney, NSW, Australia \\ Correspondence to: Yong Li, email: y.li@unsw.edu.au \\ Keywords: cancer, radiotherapy, radioresistance, CSC, signaling pathway \\ Received: October 13, $2015 \quad$ Accepted: December 22, $2015 \quad$ Published: December 24, 2015
}

\section{ABSTRACT}

Radiation therapy (RT) is one of the most important strategies in cancer treatment. Radioresistance (the failure to RT) results in locoregional recurrence and metastasis. Therefore, it is critically important to investigate the mechanisms leading to cancer radioresistance to overcome this problem and increase patients' survival. Currently, the majority of the radioresistance-associated researches have focused on preclinical studies. Although the exact mechanisms of cancer radioresistance have not been fully uncovered, accumulating evidence supports that cancer stem cells (CSCs) and different signaling pathways play important roles in regulating radiation response and radioresistance. Therefore, targeting CSCs or signaling pathway proteins may hold promise for developing novel combination modalities and overcoming radioresistance. The present review focuses on the key evidence of CSC markers and several important signaling pathways in cancer radioresistance and explores innovative approaches for future radiation treatment.

\section{INTRODUCTION}

Radiation therapy (RT) is one of the most important strategies to kill cancer cells and shrink tumor. Approximately $50 \%$ of all patients with cancer receive RT at some points in their treatment, alone or in combination with surgery and/or chemotherapy [1]. However, radioresistance and cancer recurrence are major obstacles for the long-term survival of patients undergoing RT [2, 3]. Thus, understanding the mechanisms of radioresistance is important for the improvement of RT. The mechanisms of cancer radioresistance are very complicated and affected by many factors, which severely affect radiation efficacy. One possible reason for RT failure may be the intrinsic radioresistance of a subpopulation of clonogenic cells within the tumor [4] while another reason could be the acquired radioresistance during RT $[5,6]$. The possible mechanisms of the acquired cancer radioresiatance are depicted in Figure 1.

Recently, cancer stem cell (CSC) theory has offered a potential explanation for the relapse and resistance that occur in many tumors [7]. Several lines of evidence support CSCs are associated with radiosensitivity [8-10]. In addition, different signaling pathways were reported to play important roles in cancer radioresistance $[8,11]$.

The roles of cellular hypoxia, tumor niches, tumor microenvironment, apoptosis and autophagy in cancer radioresistance have been recently reviewed $[2,12]$. Here, we focus on discussing the roles of CSCs and signaling pathways in cancer radioresistance and explore novel therapeutic modalities for future cancer RT.

\section{CSCS IN RADIORESISTANCE}

\section{Roles of CSCs in RT}

Despite continuous improvements in cancer management, locoregional recurrence or metastatic spread still occurs in a high proportion of patients after RT or combined treatments [13]. One underlying reason might be a low efficacy of current treatments on the eradication of CSCs. Despite the ongoing debate on the abundance 
and origin of CSCs, it is generally accepted that they represent the root of cancer that must be eradicated in order to cure cancer. Increasing evidence indicates that CSCs contribute to radioresistance which could result in radiation treatment failure [14]. Further studying CSCs features found that CSCs led to radioresistance, which is associated with intrinsic determinants (DNA repair capability, reactive oxygen species (ROS) levels, cell cycle status, autophagy, apoptosis, regulation of survival pathway) and extrinsic determinants (the influence of hypoxic microenvironment) $[14,15]$. Thus, investigation of CSCs has been a hot spot of basic cancer research and is rapidly expanding into many related aspects of cancer research, including radiosensitization [8].

\section{Cell cycle, DNA repair and ROS mechanisms are associated with CSCs in radioresistance}

Generally, CSC subpopulations are more related to radioresistance compared to non-CSC subpopulations [15]. One representative study demonstrated that CSC marker CD133 represented a relatively radioresistant (RR) cellular population in glioblastoma (GBM) and these CSCs were particularly resistant to radiation [16]. The role of cell cycle in radioresistance is important. The activation of cell cycle checkpoint kinases, Chk1 and Chk2, was found in $\mathrm{CD}_{133}{ }^{+} \mathrm{CSC}$ s compared with CD133- non-CSCs [17]. It was reported that U87 and U251 glioma stem cells were more RR compared to glioma cells due to high expression of phosphorylated cell cycle checkpoint proteins [18]. Activation of Chk1/2 checkpoint proteins were also found in PC-3RR, DU145RR and LNCaPRR CaP cell lines [19, 20]. Inhibition of cell cycle check point protein Chk1 was found to increase radiosensitivity in $\mathrm{CD} 133^{+} \mathrm{CD} 44^{+}$ DU145 CaP cells [21]. In laryngeal carcinoma, more cells were arrested in the $\mathrm{G}_{0} / \mathrm{G}_{1}$ phase of the cell cycle in $\mathrm{CD} 133^{+}$Hep- 2 cells with radiation treatment, compared to no treatment control [22]. CD133 ${ }^{+}$Huh-7 liver CSCs also showed greater distribution in $\mathrm{G}_{0} / \mathrm{G}_{1}$ phase than that of CD133- cells post RT [23]. Hence, abnormal expression of cell cycle related proteins may promote CSCs proliferation after radiation. These results support that cell cycle plays an important role in CSC-associated radioresistance.

DNA repair is also involved in CSC-associated radioresoistance. It was reported that enriched CSC cell populations such as $\mathrm{CD} 44^{+} / \mathrm{CD} 24^{-}$breast cancer cells and $\mathrm{CD}_{133^{+}}$glioma cells showed increasing DNA repair capability compared with non-CSC-enriched cell populations $[24,25]$. Recent evidence also demonstrated

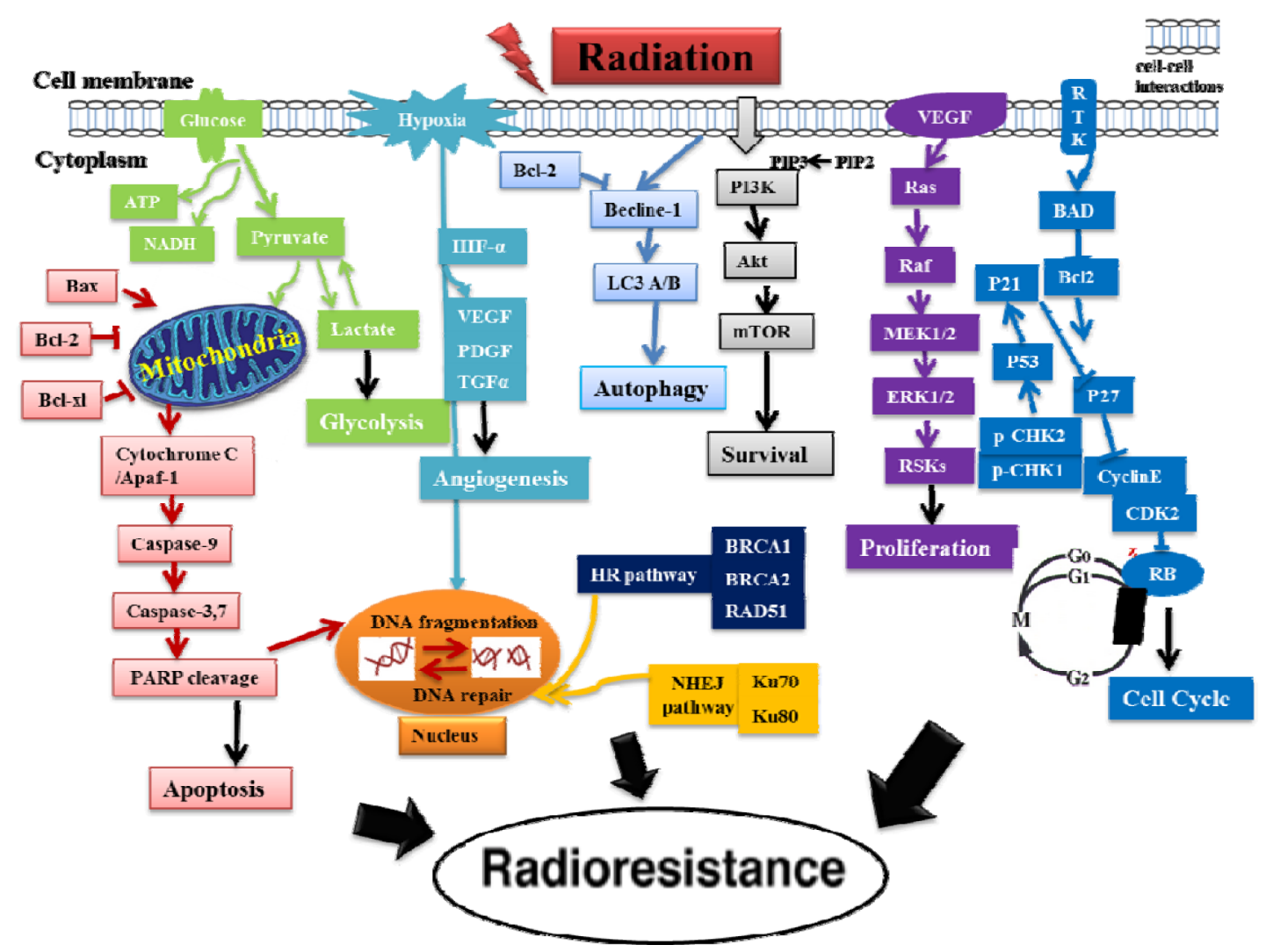

Figure 1: A schematic diagram for the putative mechanisms of the acquired cancer radioresistance after RT. This diagram shows that the induced cancer radioresistance is associated with the activation of several pathways (PI3K/Akt/mTOR, ERK, glycolysis, VEGF, autophagy, NHEJ and HR DNA repairs), the induction of cell cycle redistribution and inactivation of apoptosis pathway after exposure to radiation. Notes: ERK: Extracellular signal-regulated kinases, HR: Homologous recombination, NHEJ: Non-homologous end joining, VEGF: Vascular endothelial growth factor. 
that glioma CSCs play a crucial role in radioresistance through activation of DNA damage checkpoint proteins including ATM, SMC1, Chk1, Chk2, and p53 and increased DNA repair [26]. Zhang et al showed that CSCs exhibited more efficient DNA damage repair than bulk tumor cells when exposed to radiation [27]. Gene microarray demonstrated an increased DNA damage response and expression of DNA repair genes among Lin $^{(-)} \mathrm{CD} 29^{(\mathrm{H})} \mathrm{CD} 24^{(\mathrm{H})}$ breast cancer CSC [28]. The findings from our group also suggest that more efficient DNA repair capacity in the $\mathrm{CD} 44^{\text {high }}$ prostate cancer $(\mathrm{CaP})$ cells after radiation contributes to their survival [29].

ROS plays crucial roles in cell proliferation, differentiation, metabolism, cell death, and tumorigenesis [30-32]. ROS is one of the most important regulatory mechanisms for CSCs and CSCs overexpress ROS scavengers, in order to protect them from ROS-induced damage [33-35]. The lower levels of ROS in subsets of CSCs in some tumors compared to non-CSCs populations, potentially result in increased levels of free-radical scavenging substances, which may contribute to tumor radioresistance [35]. Pharmacological depletion of ROS scavengers in Thy $1^{+} \mathrm{CD} 24^{+}$Lin CSC-enriched breast cells markedly decreases their clonogenicity and results in radiosensitization [35]. Blazek et al reported that CD133 ${ }^{+}$ Daoy medulloblastoma cells were more RR than CD133 cells and enlargement of the $\mathrm{CD}_{133^{+}}$subpopulation by hypoxia resulted in a low level of ROS in CSCs [36], indicating ROS level is associated with CSC and radioresistance. Kim et al showed that higher expression of DNA repair and greater number of low-to-intermediate ROS cells after radiation were found in $\mathrm{LNCaP}$ prostate spheres (CSCs) compared with adherent LNCaP cells (non-CSCs), further confirming the importance of DNA repair mechanism and ROS level in $\mathrm{CaP}$ [37].

All these reports support that cell cycle, DNA repair capability and ROS contribute to CSC-associated radioresistance.

\section{Apoptosis and autophagy are linked with CSCs in radioresistance}

Apoptosis is an indispensable factor in CSCs after radiation. We recently demonstrated reduced apoptosis in CaP RR cells and enhanced CSC phenotypes at the same time [8]. Lee et al reported that 14-3-3 $\zeta$ knockdown with short hairpin RNA (shRNA) enhanced radio-induced apoptosis by reducing radioresistance in $\mathrm{CD}_{133^{+}} \mathrm{Huh} 7$ liver cancer cell lines [38]. CD133 ${ }^{+}$Huh-7 liver CSCs were found to have greater anti-apoptotic activity through increased Bcl-2 expression and radioresistance [23]. The $\mathrm{CD}_{133^{+}}$thyroid cancer cells also showed higher

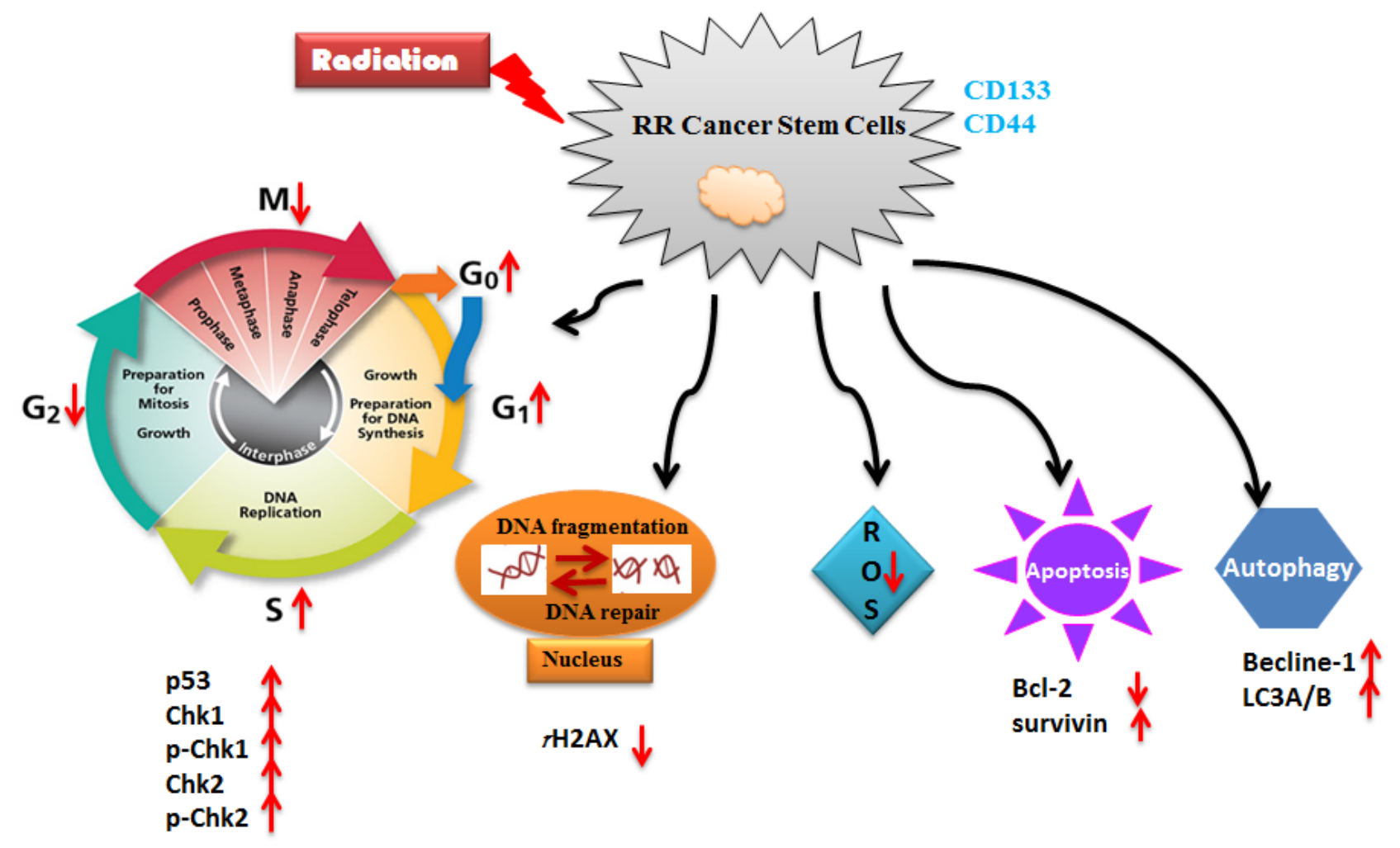

Figure 2: A schematic diagram for the mechanisms of CSCs in radioresistance. This diagram shows the possible roles of cell cycle (p53, p-Chk1, p-Chk2), DNA repair protein ( $\gamma \mathrm{H} 2 \mathrm{AX})$, ROS, apoptosis (Bcl-2 and survivin) and autophagy (Becline-1 and LC3A/B) in CSC-associated radioresistance. Notes: RR: radioresistant; ROS: reactive oxygen species. 
Table 1: CSC markers in cancer radioresistance

\begin{tabular}{|c|c|c|c|c|c|}
\hline CSC marker & Source & Cancer type & Radiation dose & \begin{tabular}{|l|} 
Testing \\
approaches
\end{tabular} & References \\
\hline CD133 & \begin{tabular}{|l|} 
CD133 ${ }^{+}$NSC11 and \\
GBMJ1 cells, \\
CD133 $3^{+}$NSC11 and \\
GBMJ1 xenografts \\
\end{tabular} & Glioblastoma & 2.9 Gy & Immunofluorescence & {$[16]$} \\
\hline $\mathrm{CD} 24^{-/ \text {low }} / \mathrm{CD} 44^{+}$ & $\begin{array}{l}\text { MCF-7 and MDA- } \\
\text { MB-231 cells }\end{array}$ & Breast cancer & $\begin{array}{l}3 \text { Gy for } 5 \\
\text { consecutive } \\
\text { days }\end{array}$ & Flow cytometry & {$[24]$} \\
\hline CD133 & $\mathrm{CD} 133^{+}$glioma cells & Glioma cancer & $5 \mathrm{~Gy}$ & Western blot, IHC & {$[44]$} \\
\hline $\begin{array}{l}\text { CD29, } \\
\text { CD24 }\end{array}$ & $\begin{array}{l}\mathrm{Lin}^{-} \mathrm{CD} 29^{+} \mathrm{CD} 24^{+} \\
\text {cells from p53 null } \\
\text { mouse mammary } \\
\text { tumors } \\
\end{array}$ & Breast cancer & 6 Gy for 2 days & $\begin{array}{l}\text { IHC, qPCR, } \\
\text { Western blot }\end{array}$ & {$[27,28]$} \\
\hline CD44 & $\begin{array}{l}\text { PC-3, PC-3M-luc, } \\
\text { and LNCaP cells }\end{array}$ & Prostate cancer & 0-8Gy & $\begin{array}{l}\text { Flow cytometry, Western } \\
\text { blot, immunofluorescence }\end{array}$ & {$[29]$} \\
\hline $\begin{array}{lr}\text { CD44, } & \text { CD24, } \\
\text { CD45, CD3, } \\
\text { CD20, CD10, } \\
\text { glycophorin A, } \\
\text { CD3, CD64 }\end{array}$ & \begin{tabular}{|l|}
$\mathrm{CD} 44^{+} \mathrm{CD} 24^{-/}$ \\
low Lin-breast CSC, CS \\
Thy $1^{+} \mathrm{CD} 24^{+}$Lin- \\
cell line and \\
xenografts \\
\end{tabular} & $\begin{array}{l}\text { Breast cancer, } \\
\text { head and neck } \\
\text { cancer }\end{array}$ & $\begin{array}{l}\text { 10Gy (cells), } \\
3 \times 5 \mathrm{~Gy} \text { or } \\
5 \times 2 \mathrm{~Gy} \\
\text { (xenografts) }\end{array}$ & qRT-PCR, flow cytometry & {$[35]$} \\
\hline CD133 & $\begin{array}{l}\text { Daoy and D283 } \\
\text { Med cell lines }\end{array}$ & Medulloblastoma & 0-10Gy & $\begin{array}{l}\text { Flow cytometry, survival } \\
\text { assay }\end{array}$ & {$[36]$} \\
\hline CD133 & LNCaP cell line & Prostate cancer & 10Gy & $\begin{array}{l}\text { Western blot, } \\
\text { flow cytometry, } \\
\text { IHC }\end{array}$ & {$[37]$} \\
\hline CD133 & $\begin{array}{l}\text { U87 and U251 cell } \\
\text { lines }\end{array}$ & $\begin{array}{l}\text { Glioma } \\
\text { cancer }\end{array}$ & 2-8Gy & $\begin{array}{l}\text { Western blot, } \\
\text { flow cytometry, } \\
\text { immunofluorescence } \\
\end{array}$ & {$[18]$} \\
\hline CD133 & $\begin{array}{l}\text { Cells from GBM } \\
\text { patients }\end{array}$ & $\begin{array}{l}\text { Glioma } \\
\text { cancer }\end{array}$ & $3 \mathrm{~Gy}$ & Western blot & {$[17]$} \\
\hline $\begin{array}{l}\text { CD133, } \\
\text { CD44 }\end{array}$ & DU145 cell line & Prostate cancer & $8 \mathrm{~Gy}$ & $\begin{array}{l}\text { Western blot, } \\
\text { RT-PCR, } \\
\text { flow cytometry }\end{array}$ & {$[21]$} \\
\hline CD133 & Hep-2 cell line & $\begin{array}{l}\text { laryngeal } \\
\text { carcinoma }\end{array}$ & 10Gy & $\begin{array}{l}\text { Flow cytometry, } \\
\text { immunofluorescence }\end{array}$ & {$[22]$} \\
\hline CD133 & Huh-7 cell line & $\begin{array}{l}\text { hepatocellular } \\
\text { carcinoma }\end{array}$ & 0-20Gy & $\begin{array}{l}\text { Western blot, } \\
\text { flow cytometry }\end{array}$ & {$[23]$} \\
\hline $\begin{array}{l}\text { CD44, CD44v6, } \\
\text { CD326, ALDH1 }\end{array}$ & $\begin{array}{l}\text { PC-3, DU145 and } \\
\text { LNCaP cell lines }\end{array}$ & Prostate cancer & $6 \mathrm{~Gy}$ & $\begin{array}{l}\text { Western blot, } \\
\text { qRT-PCR, } \\
\text { immunofluorescence }\end{array}$ & {$[20]$} \\
\hline CD133 & $\begin{array}{l}\text { CD133+ r r cell } \\
\text { line from } \\
\text { specimens }\end{array}$ & $\begin{array}{l}\text { Glioma } \\
\text { cancer }\end{array}$ & $5 \mathrm{~Gy}$ & $\begin{array}{l}\text { Western blot, } \\
\text { WST-1 assay, neurosphere } \\
\text { formation assay, } \\
\text { immunoblot analysis }\end{array}$ & {$[43]$} \\
\hline CD133 & $\begin{array}{l}\text { Huh7 CD133+ cell } \\
\text { line }\end{array}$ & Liver cancer & $15 \mathrm{~Gy}$ & $\begin{array}{l}\text { Immunofluorescence, } \\
\text { Western blot }\end{array}$ & {$[38]$} \\
\hline CD133 & $\begin{array}{l}\text { WRO, } \\
\text { CGTH, } \\
\text { CG3, } \\
\text { ARO cell lines } \\
\end{array}$ & Thyroid cancer & 10 or $20 \mathrm{~Gy}$ & $\begin{array}{l}\text { Western blot, } \\
\text { flow cytometry, } \\
\text { RT-PCR }\end{array}$ & {$[39]$} \\
\hline CD44 & MCF7 cell line & Breast cancer & $\begin{array}{l}2 \text { Gy for } 5 \text { times } \\
\text { (xenograft) }\end{array}$ & $\begin{array}{l}\text { Western blot, } \\
\text { IHC }\end{array}$ & {$[40]$} \\
\hline
\end{tabular}

Notes: IHC, immunohistochemistry; qRT-PCR, Quantitative real time-PCR; RT-PCR, reverse transcription polymerase chain reaction 
anti-apoptotic rate after radiation [39]. Dahan et al demonstrated that radiation induced reprogramming in glioblastomas stem-like cells from patients was associated with the up-regulation of the anti-apoptotic protein survivin [9]. In breast cancer, the increased radioresistance in $\mathrm{HER}^{+} / \mathrm{CD} 44^{+} / \mathrm{CD} 24^{- \text {low }} \mathrm{MCF} 7$ cells was found to be correlated with significantly reduced apoptosis [40].

In recent years, the role of autophagy as an alternative cell death mechanism has been a topic of debate. Autophagy was believed as a non-apoptotic programme of cell death or "type-II" cell death to distinguish from apoptosis [41]. In cancer therapy, the role of autophagy is paradoxical, in which this cellular process may serve as a pro-survival or pro-death mechanism to counteract or mediate the cytotoxic effect of anticancer agents [42]. To date, there is only little evidence for the role of autophagy in CSC-associated radioresistance. It was found that radiosensitivity of glioma stem cells can be increased by inhibiting autophagy-related proteins Becline-1 and ATG5, indicating that the induction of autophagy contributes to radioresistance of glioma stem cells [43]. Our recent data support that $\mathrm{CaP}$ radioresistance is associated with apoptosis and autophagy pathways and that autophagy promotes CaP RR cell survival [20].

All above-mentioned findings imply that multiple mechanisms contribute to CSCs in radioresistance and targeting CSC markers or these mechanisms holds promise to overcome cancer radioresistance and improve radiosensitivity. The possible roles of cell cycle, DNA repair, ROS, apoptosis and autophagy in CSC-associated radioresistance is shown in Figure 2. The putative CSC makers in radioresistance are summarized in Table 1. All researches provide a vision that CSCs regulate radioresistance.

\section{SIGNALING PATHWAYS IN CANCER RADIORESISTANCE}

Accumulating evidence from human cancer tissues and preclinical studies indicates that different signaling pathways play a critical role in cancer progression, metastasis and chemo/radioresistance via the activation of the pathway proteins or mutation, deletion, epigenetically silence of some pathway genes [8, 45]. Understanding the signaling pathways that determine radioresistance is vital for selecting appropriate treatment modalities for patients and developing novel molecular agents to enhance radiosensitivity in human cancers. In this section, we focus on several important signaling pathways that are highly associated with cancer radioresistance and also discuss the link of CSCs with these signaling pathways in radioresistance. The roles of different signaling pathways associated with CSCs in radioresistance are shown in Figure 3.

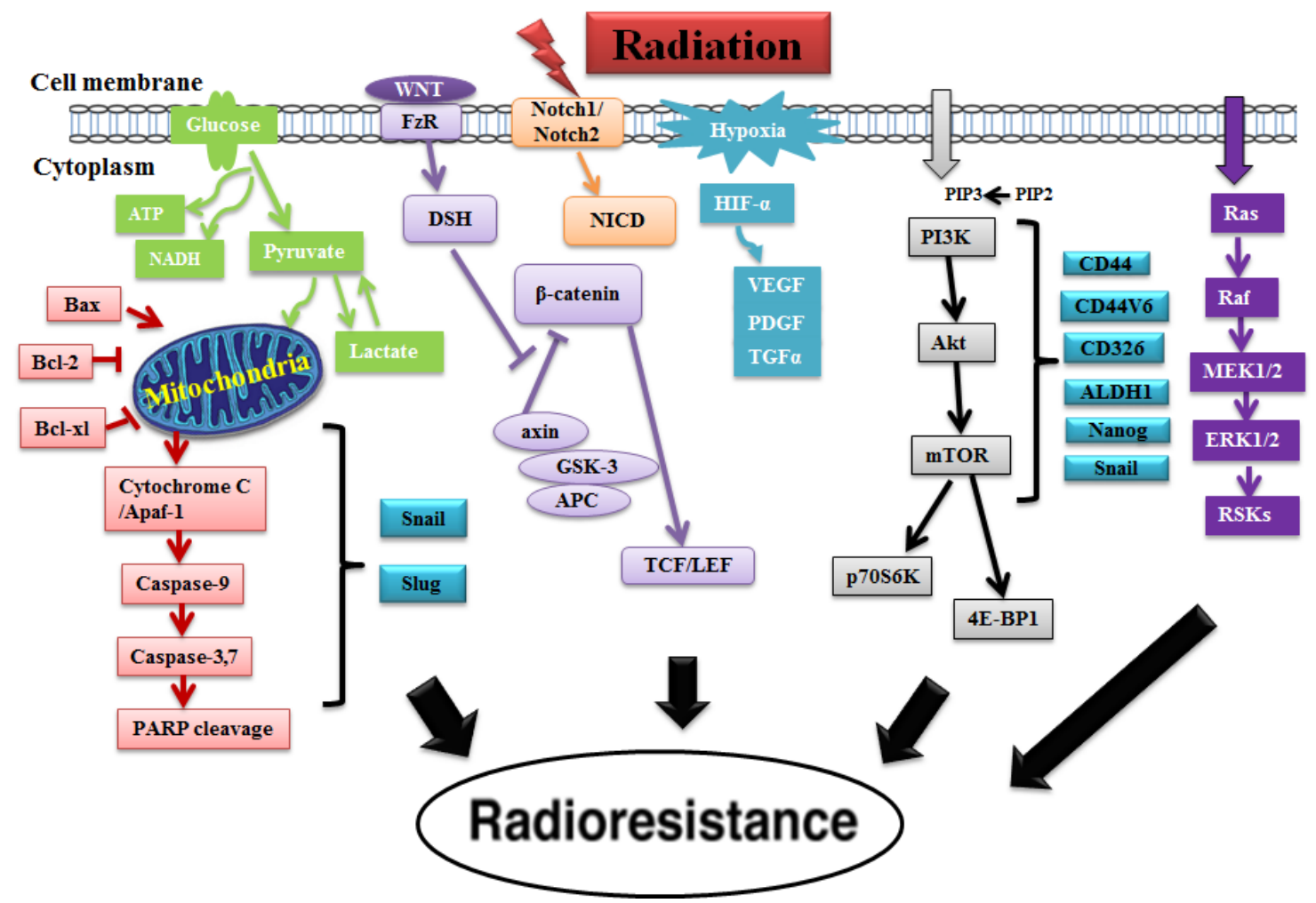

Figure 3: The roles of different signaling pathways associated with CSCs in radioresistance. This diagram shows that cancer radioresistance is associated with several different pathways (PI3K/Akt/mTOR, ERK, glycolysis, VEGF, Notch and WNT/ $\beta$-catenin pathway) as well as CSCs. We have recently demonstrated that the PI3K/Akt/mTOR signaling pathway is associated with the regulation of CSC phenotypes (CD44, CD44v6, CD326, ALDH1, Nanog and Snail) in CaP radioresistance [8]. Notes: FzR: Frizzled receptor. 


\section{PI3K/Akt/mTOR pathway}

PI3K/Akt/mTOR pathway plays an important role in cell growth and proliferation, and is often dysregulated in cancer due to mutation, amplification, deletion, methylation and post-translational modifications. This pathway is an intracellular signaling pathway important for apoptosis, malignant transformation, tumor progression, metastasis and radioresistance $[8,46]$. Datta et al found that radiation could persistently activate mTOR via PI3K/Akt pathway in mouse intestine [47]. Skvortsova et al reported that radioresistance in $\mathrm{CaP}$ is accompanied by the activation of the PI3K/Akt/mTOR pathway [11]. Similarly, our recent study also found the PI3K/Akt/mTOR signaling pathway is associated with $\mathrm{CaP}$ radioresistance in $\mathrm{CaP}$ RR cell lines and enhanced CSC phenotypes (CD44, CD44v6, CD326, ALDH1, Nanog and Snail) [8] (Figure 3). We further confirmed that enhanced CSCs is regulated by the PI3K/Akt/mTOR pathway [8]. Zhu et al demonstrated that a dual PI3K/mTOR inhibitor BEZ235 prominently improved the radiosensitivity of PC-3 CaP cells [48]. Our recent results showed that combination of dual PI3K/mTOR inhibitors (BEZ235 or PI103) with $\mathrm{RT}$ could overcome $\mathrm{CaP}$ radioresistance in vitro [20]. We also found that knockdown of CSC marker EpCAM with small interfering RNA (siRNA) could down-regulate the PI3K/Akt/mTOR pathway proteins and enhance radiosensitivity in CaP cells in vitro [49]. It was found that radiation activated the Akt/mTOR/4EBP/eIF4E signaling pathway in the A549 lung cancer cell line [50]. Heavey et al recently reviewed that inhibition of this pathway in non-small cell lung cancer (NSCLC) might result in the improvement of RT and overcome radioresistance [51]. Kim et al reported that radiation bestowed activation of the $\mathrm{PI} 3 \mathrm{~K} / \mathrm{Akt} / \mathrm{mTOR}$ pathway upon lung cancer by inducing hypoxia-inducible factor-1 $\alpha$ (HIF-1 $\alpha$ ) and blocking HIF$1 \alpha$ could circumvent radioresistance in lung cancer cells [52].

The PI3K/Akt/mTOR pathway was reported to play important roles in radiation-induced autophagy in glioma cells [53]. Liu et al demonstrated that two dual PI3K/ mTOR inhibitors, GSK2126458 and PKI-587, suppressed tumor progression and increased radiosensitivity in nasopharyngeal carcinoma (NPC) [54]. Chen et al found that the dual PI3K/mTOR inhibitor BEZ235 with radiation enhanced the radiosensitivity of colorectal cancer cells both in vitro and in vivo [55]. Mehta et al recently showed that using a low dose of AKT-i (Akt inhibitor) could sensitize radiation in primary human glioblastoma stemlike cells in vitro [56]. Therefore, the PI3K/Akt/mTOR pathway is an important pathway in the regulation of cancer radioresponse.

\section{ERK pathway}

Extracellular signal-regulated kinases (ERK) pathway (also known as the mitogen-activated protein kinases (MAPK)/ERK pathway or Ras-Raf-MEK-ERK pathway) is a chain of proteins that communicates from the cell surface to the DNA and regulates the development of many cancers. ERK pathway has become a major player in response to DNA damage. Increasing evidence has shown that this pathway is related to the cellular response to ionizing radiation (IR), suggesting a role in radioresistance (Figure 3) [57]. ERK pathway was found to be involved in HER2-overexpressing breast cancer cell radioresistance [58]. Inhibition of ERK was correlated with the reduced cell growth and clonogenic survival in human RR esophageal carcinoma cells KYSE-150RR [59]. Xie et al reported that radiosensitivity was regulated by inactivation of ERK pathway proteins including p38, ERK, JNK in A375 human melanoma cells [60]. Marampon et al showed that ERK pathway, through the sustained expression of DNA-PKcs, positively regulated HIF-1 $\alpha$ protein expression and activity, preserving GBM radioresistance in hypoxic condition [61]. Huang et al found that the phosphorylation of Raf-1 and ERK was up-regulated in RR cervical cancer cell lines HeLa and C33A [62]. The MEK/ERK cascade can also regulate tumor radioresistance in a panel of gynecological cancer cell lines including Ishikawa (endometrial cancer), HeLa (cervical cancer), CASKI (cervical cancer) and SiHa (cervical cancer) cell lines [63]. It was reported that this pathway was activated in head and neck squamous cell carcinoma (HNSCC) radioresistance and the expression of p-ERK was found to be decreased by MAPK inhibitor U0126 combined with radiation treatment with increased radiation response [64]. Affolter et al also showed that U0126 significantly reduced the level of p-ERK and suppressed colony forming ability in radiated oral squamous cancer cells HNSCCUM-02T and lung cancer cells A549 [65]. However, Gupta et al claimed that inhibition of the Raf-MEK-MAPK pathway with PD98059, or the Ras-MEK kinase-p38 pathway with SB203580 had no effect on radiation survival in cells with oncogenic Ras gene [66]. The reason could be that although the Raf-MAPK pathway might be a mediator of altered radiosensitivity in some systems, it was not the downstream mediator of Ras-induced radioresistance [66]. Unlike this study, our data indicate ERK pathway (overexpression of p-ERK) is activated in PC-3RR cells and PC-3RR subcutaneous (s.c) xenograft tumors (Figure 4), respectively, indicating that ERK pathway activation does contribute to radioresistance in $\mathrm{CaP}$. These studies support that targeting ERK pathway may enhance the efficiency of RT. 


\section{Glycolysis pathway}

Glycolysis pathway, located in the cytoplasm of eukaryotic cells, is the metabolic pathway that is responsible for the production of adenosine triphosphate (ATP) through the degradation of glucose. Tumor malignancy could be caused by energy metabolism resulting from the increased glycolytic pathway [67]. Recent reports demonstrate that CSCs rely on glycolysis pathway in several cancers including breast cancer, laryngeal cancer, nasopharyngeal cancer as well as glioma [68-71]. In our study, glycolysis pathway (overexpression of MCT1, MCT4 and CD147) was found to be activated in PC-3RR cell line and PC-3RR CaP xenograft tumor tissues (Figure 4). Bing et al reported that glycolysis might impede radiation treatment in RR HeLa cervical cancer cell line [72]. It was found that expression of glucose transporter Glut1 and lactate production rate were increased in RR HepG2 liver cancer cells and HeLa cervical cancer cells compared with parental cells, respectively [73]. One study indicated that RR OE33 esophageal adenocarcinoma cells showed significantly increased intracellular ATP levels and the expression of ATP5B, HSP60, GAPDH as well as pyruvate kinase M2 isoform (PKM2) proteins, suggesting the activation of oxidative phosphorylation and glycolysis [74]. Pitroda et al reported that knockdown of STAT1 with shRNA led to significant growth suppression of irradiated tumors and improved radiosensitization in human squamous cell carcinoma cell line SCC61, accompanied by alterations in glycolysis pathway [75]. Knockdown of PKM2 (a key regulator of glycolysis) with shRNA enhanced the radiosensitivity of A549 NSCLC cells in vitro and s.c xenografts in vivo [76]. The role of glycolysis pathway in radioresistance is shown in Figure 3. Lactate dehydrogenase A (LDHA) is a main metabolic enzyme for lactate production which is a terminal product from glycolysis. It plays an essential role in the glycolysis. Our recent findings indicated that increased LDHA was found in CaP RR cells and knockdown of LDHA with siRNA or specific inhibitor FX-11 can increase radiosensitivity in CaP RR cells (unpublished data), suggesting LDHA is associated with $\mathrm{CaP}$ radioresistance. Thus, targeting glycolysis pathway is likely to have broad therapeutic applications for cancer radioresistance.

\section{VEGF pathway}

Angiogenesis is involved in pathogenesis, progression and metastasis in a variety of solid tumors. VEGF signaling pathway that is stimulated by upstream activators including environmental cues, growth factors, oncogenes, cytokines and hormones is a critically important growth factor pathway which stimulates vasculogenesis and angiogenesis. Overexpression of VEGF contributes to the growth and metastasis of

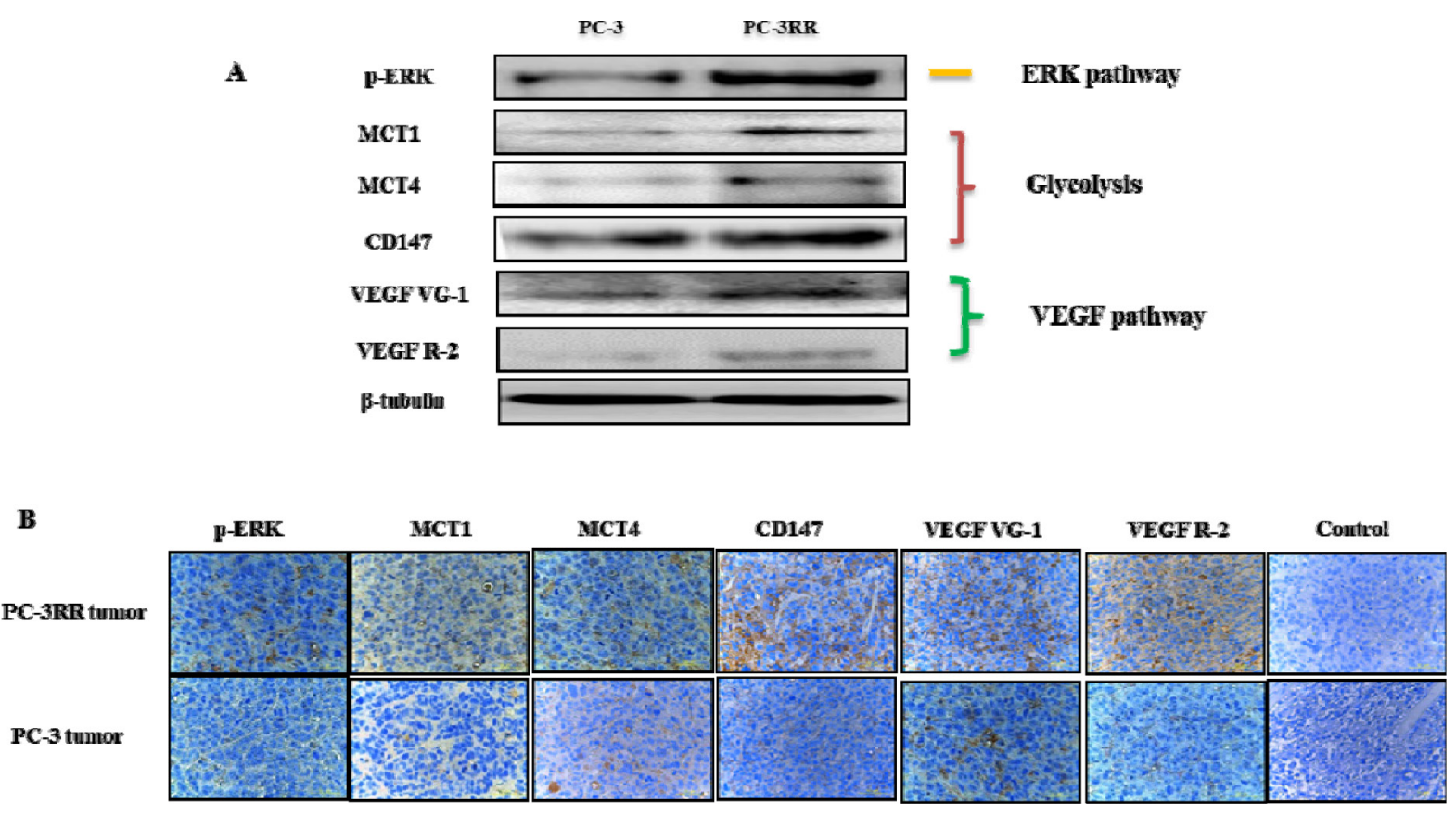

Figure 4: Overexpression of key proteins from ERK, Glycolysis, VEGF pathways observed in PC-3RR cell line and PC-3RR s.c xenograft tumors. A. The representative images showing increased expression of p-ERK, MCT1, MCT4, CD147, VEGF VG-1 and VEGF R-2 (pathway associated proteins) in PC-3RR CaP cells compared with PC-3 cells by Western blotting. $\beta$-tubulin was used as a loading control. B. Representative images showing increased expression of p-ERK, MCT1, MCT4, CD147, VEGF VG-1 and VEGF R-2 in PC-3RR s.c. xenografts compared to parental PC-3 xenografts using immunohistochemistry. Brown indicates positive staining while blue indicates nuclear staining. Magnification in all images $x 40$. All data were from three independent experiments $(n=3)$. 
solid tumors and inhibition of VEGF pathway offers potential clinical treatment for patients with hematologic malignancies [77]. The transcriptional regulation of VEGF pathway is associated with radiation by up-regulation of HIF- $1 \alpha$ and $\mathrm{NF}-\kappa \mathrm{B}$ in $\mathrm{CaP}[78,79]$. It was found that the expression of HIF-1 $\alpha / \mathrm{VEGF}-\mathrm{A}$ was suppressed in improved radiosensitivity in endometrial cancer cell lines HEC-6 (TP53 wild-type) and HEC-1B (TP53 mutant) [80]. Tian et al showed that eukaryotic translation initiation factor 4F (eIF4F) complex played a pivotal role in regulation of radiosensitivity by controlling the expression of VEGF and basic fibroblast growth factor (bFGF), two well-known pro-angiogenic factors [81]. Upregulation of VEGF expression was shown in radiation induced murine squamous cancer cells NR-S1 [82]. Blocking radiation-induced VEGF pathway in CaP was found to interfere with tumor growth [45]. Several similar pieces of evidence were also demonstrated in HNSCC. The release of VEGF protein is increased during RT in HNSCC, which could be important for therapy success $[64,83]$. The role of VEGF pathway in radioresistance is shown in Figure 3. In our recent studies, we also found the activation of this pathway with increased expression of VEGF VG-1 and VEGF R2 in PC-3RR CaP cell line and PC-3RR CaP xenograft mouse model (Figure 4). Thus, radiation-induced changes in VEGF pathway may modulate microenvironment and influence responsiveness of tumors to RT.

\section{Notch pathway}

Notch pathway is a well-known CSC pathway [84]. This pathway is a highly conserved cell signaling system present in a wide range of human tumors such as leukemia [85], breast cancer [86], and glioma [87] through regulating self-renewal and repressing differentiation [88, 89]. It was reported that Notch pathway was activated in endothelial cells by IR shifting up-regulation of Jag1 and Heyl [90]. High Notch pathway activity showed correlation with poor prognosis and radioresistance in NSCLC patients [91]. The result that inhibition of Notch pathway with gamma-secretase inhibitors (GSIs) rendered the glioma stem cells more sensitive to radiation at clinically relevant doses, suggests a critical role of Notch signaling to regulate radioresistance of glioma stem cells [92]. According to Zhang et al, inhibiting Notch-1 could regulate radiation-induced epithelial-mesenchymal transition (EMT) in gastric cancer cells [93]. Inhibiting radiation-induced Notch-1 signaling was found to enhance the RT efficacy in NCI-H1299 and NCI-H460 NSCLC cell lines in vitro and NCI-H1299 s.c xenografts in vivo [94]. It was recently reported that the non-adherent anoikisresistant stem cell-like $\mathrm{CaP}$ cell population after RT showed activation of the Notch pathway and increased expression of stem cell markers CD133, Oct-4, Sox2 and Nanog [95]. All results suggest that Notch pathway inhibition could be developed as an adjuvant approach to improve current radiation treatment for human cancer. The role of the Notch pathway in cancer radioresistance is shown in Figure 3.

\section{Wnt/ß-catenin pathway}

Wnt/ $\beta$-catenin pathway is another CSC pathway [84]. This pathway was reported to be associated with cancer metastasis in breast, lung and prostate cancers [96-98]. This pathway was also found to be involved in CSC radioresistance [99]. The role of the Wnt/ $\beta$-catenin pathway in radioresistance is demonstrated in Figure 3. Su et al showed that the up-regulation of the $\mathrm{Wnt} / \beta$-catenin pathway is important for KYSE-150 RR esophageal cancer cells $[100,101]$. The downregulation of miR301a promoted radioresistance in RR esophageal cell line KYSE-150R through the upregulation of Wnt1, indicating that $\mathrm{Wnt} / \beta$-catenin signal pathway plays an important role in radioresistance [100]. Bastos et al observed that the irradiated colorectal cancer cells Caco-2, HT-29 and HCT116 showed increased Wnt/ $\beta$-catenin-dependent TCF/LEF activity [102]. Inhibition of $\mathrm{Wnt} / \beta$-catenin pathway could radiosensitize $\mathrm{CaP}$ cells through decreasing aldehyde dehydrogenase (ALDH) [103]. Targeting a downstream marker of Wnt/ $\beta$-catenin pathway WISP1 could sensitize esophageal squamous cell carcinoma (ESCC) to irradiation [104]. Zhang et al showed that WISP1 facilitated its own expression in response to radiation, created a positive feedback loop and increased radioresistance [104]. Thus, the radiosensitivity of cancer cells can be enhanced by inhibiting the Wnt/ $\beta$-catenin pathway.

In summary, several important signaling pathways are closely associated with CSCs and radioresistance. These pathways constitute important targets for new adjuvant treatment schedules with RT, with the goal of reducing the migratory and invasive potential of the remaining cancer cells after treatment. The roles of different signaling pathways in cancer radiation response are summarized in Table 2.

\section{Proteomic technologies in cancer RR signaling pathway research}

During the past few years, emerging proteomics technologies have been applied to study signaling pathways associated with cancer radioresistance. These proteomics techniques include two-dimensional difference gel electrophoresis (2D-DIGE), liquid chromatographytandem mass spectrometry (LC-MS/MS) and multiple reaction monitoring (MRM). Using 2D-DIGE approache, Skvortsova et al compared the protein differences between three CaP RR cell lines (PC3-RR, DU145-RR and LNCaP-RR) and their parental cells to examine the involved signaling pathways and found $\mathrm{CaP}$ RR cells 
Table 2: Different signaling pathways in cancer radioresistance

\begin{tabular}{|c|c|c|c|c|c|}
\hline Signaling pathway & Source & Cancer & Radiation dose & Validation & Reference \\
\hline \multirow{8}{*}{$\begin{array}{l}\text { PI3K/Akt/ } \\
\text { mTOR } \\
\text { pathway }\end{array}$} & \begin{tabular}{|l} 
PC-3, \\
DU145, \\
LNCaP cell lines \\
\end{tabular} & prostate cancer & $6 \mathrm{~Gy}$ & Western blot & {$[8]$} \\
\hline & C57BL/6J female mice xenograft & colorectal cancer & 2Gy & $\begin{array}{l}\text { QRT-PCR, } \\
\text { flow cytometry, } \\
\text { IHC, } \\
\text { immunofluorescence }\end{array}$ & {$[47]$} \\
\hline & \begin{tabular}{|l|} 
PC-3, \\
DU145, \\
LNCaP cell lines \\
\end{tabular} & prostate cancer & 2Gy & Western blot, ELISA & {$[11]$} \\
\hline & PC-3 cell line & prostate cancer & $4 \mathrm{~Gy}$ & $\begin{array}{l}\text { Flow cytometry, } \\
\text { Western blot } \\
\end{array}$ & [48] \\
\hline & $\begin{array}{l}\text { A549, } \\
\text { H1299 cell lines, } \\
\text { A549 subcutaneously } \\
\text { xenograft }\end{array}$ & lung cancer & 25 or $50 \mathrm{~Gy}$ & $\begin{array}{l}\text { IHC, } \\
\text { Western blot, } \\
\text { RT-PCR }\end{array}$ & {$[50]$} \\
\hline & $\begin{array}{l}\text { H1299, } \\
\text { H226B, } \\
\text { H226Br, } \\
\text { H460, } \\
\text { H182 cell lines, } \\
\text { animal xenograft } \\
\end{array}$ & lung cancer & $3 \mathrm{~Gy}$ & $\begin{array}{l}\text { Western blot, } \\
\text { RT-PCR, } \\
\text { immunoprecipitation }\end{array}$ & {$[52]$} \\
\hline & $\begin{array}{l}\text { CNE-2, } \\
5-8 \mathrm{~F}, \\
6-10 \mathrm{~B} \text { cell lines }\end{array}$ & nasopharyngeal cancer & $\begin{array}{|lr|}4 \text { Gy (cells); } \\
2 \quad \text { Gy } & \text { every } \\
\text { other day for } \\
\text { four treatments } \\
\text { (xenograft) } \\
\end{array}$ & $\begin{array}{l}\text { IHC, } \\
\text { TUNEL }\end{array}$ & {$[54]$} \\
\hline & \begin{tabular}{|l|} 
HCT 116, \\
SW 620, \\
HT 29 cell lines, \\
HCT116 subcutaneously \\
xenograft \\
\end{tabular} & colorectal cancer & $\begin{array}{l}5 \mathrm{~Gy} / \text { fraction, three } \\
\text { times in one week }\end{array}$ & $\begin{array}{l}\text { IHC, } \\
\text { Western blot }\end{array}$ & {$[55]$} \\
\hline \multirow{13}{*}{ ERK pathway } & $\begin{array}{l}\text { HCT116, } \\
\text { HT29, } \\
\text { RKO, } \\
\text { HCT15 cell lines } \\
\end{array}$ & colorectal cancer & $6 \mathrm{~Gy}$ & $\begin{array}{l}\text { Western blot, } \\
\text { qRT-PCR }\end{array}$ & {$[57]$} \\
\hline & \begin{tabular}{|l} 
H460, \\
H1299 cell lines \\
\end{tabular} & non-small-cell lung cancer & $6 \mathrm{~Gy}$ & $\begin{array}{l}\text { Western blot, } \\
\text { qRT-PCR } \\
\end{array}$ & {$[57]$} \\
\hline & \begin{tabular}{|l|} 
U87MG, \\
T98G cell lines \\
\end{tabular} & glioblastoma & $6 \mathrm{~Gy}$ & $\begin{array}{l}\text { Western blot, } \\
\text { qRT-PCR } \\
\end{array}$ & {$[57]$} \\
\hline & $\begin{array}{l}\text { 769P, } \\
\text { ACHN cell lines }\end{array}$ & clear cell renal cell cancer & 6Gy & $\begin{array}{l}\text { Western blot, } \\
\text { qRT-PCR }\end{array}$ & {$[57]$} \\
\hline & $\begin{array}{l}\text { MDA-MB-231, MCF7 wild type, } \\
\text { MCF7/HER2, MCF7/C6 cell lines } \\
\end{array}$ & breast cancer & $10 \mathrm{~Gy}$ & $\begin{array}{l}\text { Western blot, } \\
\text { immunoblotting }\end{array}$ & {$[58]$} \\
\hline & KYSE-150 cell line & esophageal cancer & $2 \mathrm{~Gy}$ or $6 \mathrm{~Gy}$ & $\begin{array}{l}\text { Western blot, } \\
\text { immunoblotting, } \\
\text { immunofluorescence } \\
\end{array}$ & {$[59]$} \\
\hline & A375 cell line & melanoma & $8 \mathrm{~Gy}$ & $\begin{array}{l}\text { Western blot, } \\
\text { flow cytometry, ROS }\end{array}$ & {$[60]$} \\
\hline & HeLa cell line & cervical cancer & $8 \mathrm{~Gy}$ & $\begin{array}{l}\text { Western blot, } \\
\text { flow cytometry, ROS }\end{array}$ & {$[60]$} \\
\hline & \begin{tabular}{|l|} 
T98G, \\
U138MG cell lines \\
\end{tabular} & glioblastoma & $4 \mathrm{~Gy}$ & $\begin{array}{l}\text { Immunoblotting, } \\
\text { Western blot }\end{array}$ & {$[61]$} \\
\hline & \begin{tabular}{|l|}
$293 \mathrm{~T}$, \\
HeLa, \\
C33A cell lines \\
\end{tabular} & cervical cancer & 6Gy & $\begin{array}{l}\text { Immunoprecipitation, } \\
\text { Western blot, } \\
\text { RT-PCR }\end{array}$ & {$[62]$} \\
\hline & \begin{tabular}{|l|} 
HeLa, \\
CASKI, \\
SiHa cell lines \\
\end{tabular} & cervical cancer & $4 \mathrm{~Gy}$ & $\begin{array}{l}\text { Western blot, } \\
\text { flow cytometry }\end{array}$ & {$[63]$} \\
\hline & HNSCCUM-02T cell line & $\begin{array}{l}\text { head and neck squamous } \\
\text { cell cancer }\end{array}$ & 30Gy & \begin{tabular}{|l} 
ROS, \\
SDS-PAGE, \\
Western blot, \\
ELISA, \\
IHC \\
\end{tabular} & {$[64]$} \\
\hline & T24 cell line & bladder cancer & $1.6 \mathrm{~Gy}$ & Western blot & {$[66]$} \\
\hline
\end{tabular}




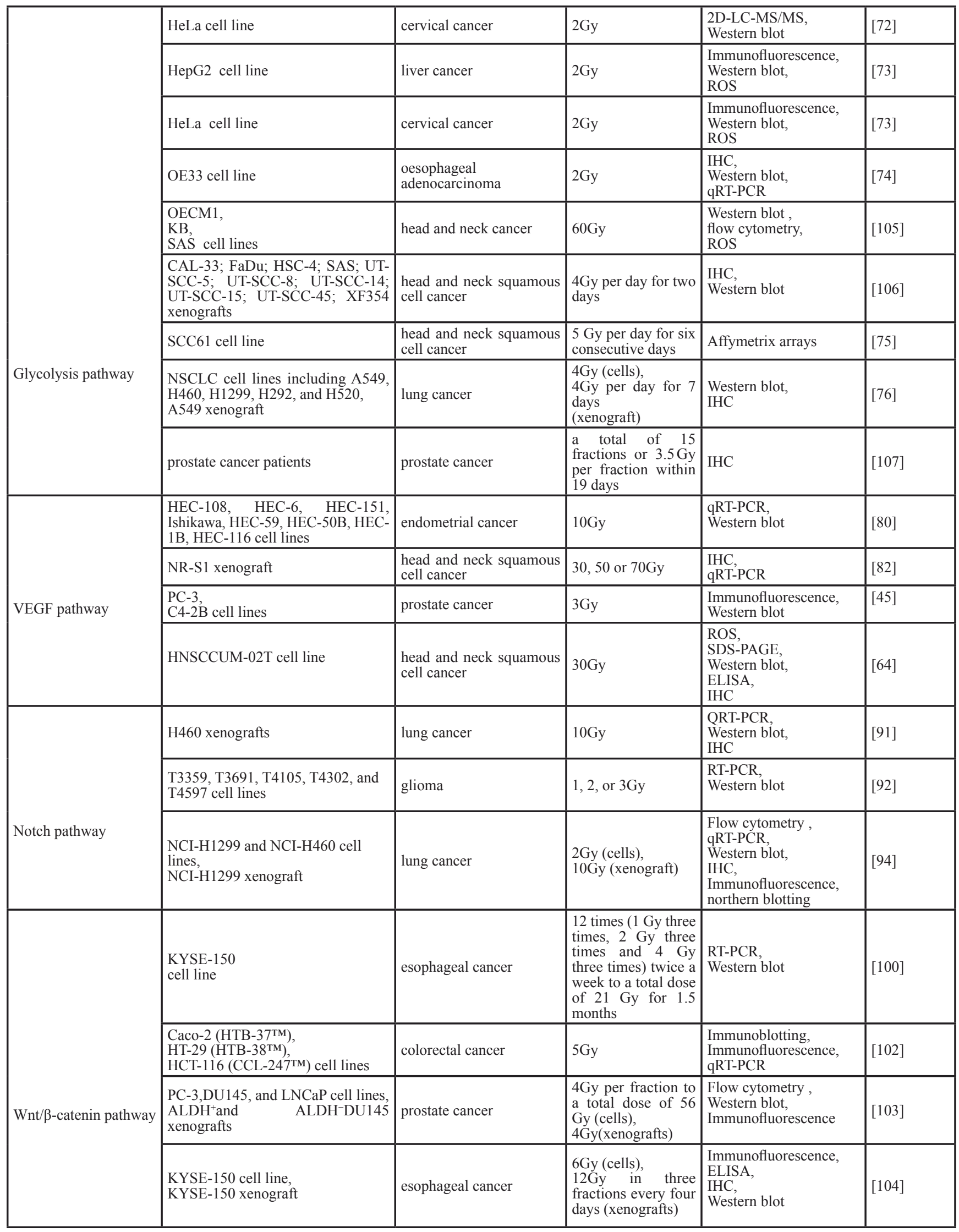

Notes: IHC, immunohistochemistry; qRT-PCR, Quantitative real time-PCR; ROS, reactive oxygen species; RT-PCR, reverse transcription polymerase chain reaction; SDS-PAGE, sodium dodecyl sulfate polyacrylamide gel electrophoresis; 2D LC-MS/ MS, two-dimensional liquid chromatography-tandem mass spectrometry. 


\section{PC3 vs PC-3RR}

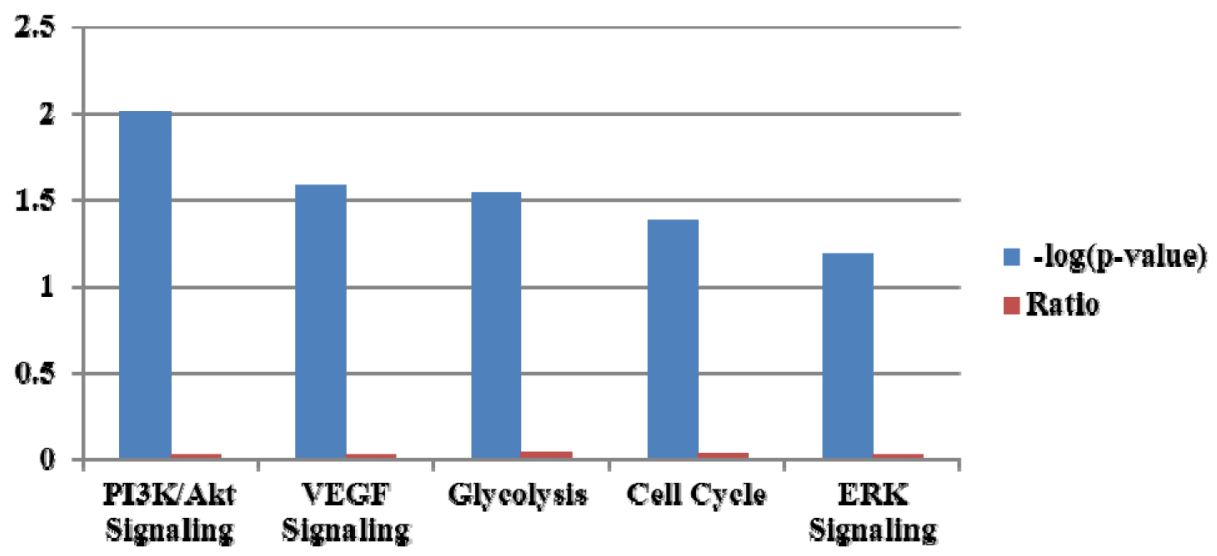

Figure 5: The top five potential pathways associated with prostate cancer radioresistance identified by label-free LC-MS/MS approach. The $p$ value and ratio of the identified top five potential pathways are displayed by Ingenuity pathway analysis between PC-3 and PC-3RR cells. The identified top five signaling pathways are PI3K/Akt, VEGF, glycolysis, cell cycle and ERK.

exhibited higher levels of androgen and epidermal growth factor (EGF) receptors and activation of their downstream pathways, including MAPK and PI3K/Akt and Jak-STAT [11]. In our recent study, total 309 signaling pathway proteins were identified to be significantly different between CaP RR (PC-3RR, DU145RR and LNCaPRR) and control (PC-3, DU145 and LNCaP) cells using the label-free LC-MS/MS method (unpublished data). Our results demonstrated that 5 signaling pathways including $\mathrm{PI} 3 \mathrm{~K} / \mathrm{Akt} / \mathrm{mTOR}$, ERK, glycolysis, VEGF, as well as cell cycle were closely associated with $\mathrm{CaP}$ radioresistance (Figure 5). These technologies provide us with a broad vision and confident results to examine signaling pathway networks or new signaling pathway proteins in cancer radioresistance.

\section{CONCLUSIONS AND FUTURE DIRECTIONS}

CSC and signaling pathway research continue to be an expanding field. The mechanisms of cancer radioresistance are still not fully uncovered. A better understanding of CSCs and associated signaling pathways that regulate radioresistance will hopefully open a new field of treatment strategies for cancer RT. The recent identity of CSCs has unlocked a new potential avenue for radioresistance research. Elucidating the role of CSCs and signaling pathways in the cancer cells' response to radiation will enhance our understanding of cancer recurrence after RT, and may direct research towards novel and specific radiosensitization agents that target CSCs or these pathway proteins.

Future clinical research designs should consider prospectively incorporating pre-treatment tumor biopsies during and after the RT course to track CSC phenotypes or signaling pathway proteins in a temporal manner. We expect that there will be increased understanding of the intrinsic and extrinsic factors that control the plasticity and maintenance of the CSC state. Due to complex and dynamic processes during fractionated RT, different RR signaling pathways may be better targeted at different stages of therapy to reduce the dependence of dose escalation. In addition, new inhibitors (radiosensitizers) should be developed to selectively target CSC and cancerassociated signaling pathway, and to reduce the toxicity to normal tissues. In the long term, any therapeutic strategy in RT will need to be taken into account of the biological features that control CSC behaviour and signaling pathway mechanisms to allow the implementation of personalized therapy.

\section{ACKNOWLEDGMENTS}

Our study was supported in part by a NHMRC Career Development Fellowship (630664) (YL); Cancer Research Trust Fund (Cancer Care Centre, St George Hospital); and Prostate and Breast Cancer Foundation (PBCF) and China Scholarship Council (LC). The authors thank Mr Ken Hopper, Mr Ese Enari, Mr Alex Wallace and Mr Peter Treacy from Cancer Care Centre for technical support.

\section{CONFLICTS OF INTEREST}

The authors declare no conflict of interest.

\section{REFERENCES}

1. Delaney G, Jacob S, Featherstone C and Barton M. The role of radiotherapy in cancer treatment: estimating optimal utilization from a review of evidence-based clinical guidelines. Cancer. 2005; 104:1129-1137. 
2. Begg AC, Stewart FA and Vens C. Strategies to improve radiotherapy with targeted drugs. Nature reviews Cancer. 2011; 11:239-253.

3. Ogawa K, Yoshioka Y, Isohashi F, Seo Y, Yoshida K and Yamazaki H. Radiotherapy targeting cancer stem cells: current views and future perspectives. Anticancer research. 2013; 33:747-754.

4. West CM, Davidson SE, Elyan SA, Swindell R, Roberts SA, Orton CJ, Coyle CA, Valentine H, Wilks DP, Hunter $\mathrm{RD}$ and Hendry JH. The intrinsic radiosensitivity of normal and tumour cells. International journal of radiation biology. 1998; 73:409-413.

5. Balmukhanov SB, Yefimov ML and Kleinbock TS. Aquired Radioresistance of Tumour Cells. Nature. 1967; 216:709711.

6. Wei K, Kodym R and Jin C. Radioresistant cell strain of human fibrosarcoma cells obtained after long-term exposure to x-rays. Radiation and environmental biophysics. 1998; 37:133-137.

7. Puhr M, Hoefer J, Schafer G, Erb HH, Oh SJ, Klocker H, Heidegger I, Neuwirt H and Culig Z. Epithelial-tomesenchymal transition leads to docetaxel resistance in prostate cancer and is mediated by reduced expression of miR-200c and miR-205. Am J Pathol. 2012; 181:21882201.

8. Chang L, Graham PH, Hao J, Ni J, Bucci J, Cozzi PJ, Kearsley JH and Li Y. Acquisition of epithelialmesenchymal transition and cancer stem cell phenotypes is associated with activation of the PI3K/Akt/mTOR pathway in prostate cancer radioresistance. Cell Death and Disease. 2013; 4:e875-e875.

9. Dahan P, Martinez Gala J, Delmas C, Monferran S, Malric L, Zentkowski D, Lubrano V, Toulas C, Cohen-Jonathan Moyal E and Lemarie A. Ionizing radiations sustain glioblastoma cell dedifferentiation to a stem-like phenotype through survivin: possible involvement in radioresistance. Cell death \& disease. 2014; 5:e1543.

10. Ventela S, Sittig E, Mannermaa L, Makela JA, Kulmala J, Loyttyniemi E, Strauss L, Carpen O, Toppari J, Grenman R and Westermarck J. CIP2A is an Oct4 target gene involved in head and neck squamous cell cancer oncogenicity and radioresistance. Oncotarget. 2015; 6:144-158. doi: 10.18632/oncotarget.2670.

11. Skvortsova I, Skvortsov S, Stasyk T, Raju U, Popper BA, Schiestl B, von Guggenberg E, Neher A, Bonn GK, Huber LA and Lukas P. Intracellular signaling pathways regulating radioresistance of human prostate carcinoma cells. Proteomics. 2008; 8:4521-4533.

12. Mannino M and Chalmers AJ. Radioresistance of glioma stem cells: intrinsic characteristic or property of the 'microenvironment-stem cell unit'? Molecular oncology. 2011; 5:374-386.

13. Koch U, Krause M and Baumann M. Cancer stem cells at the crossroads of current cancer therapy failures--radiation oncology perspective. Seminars in cancer biology. 2010; 20:116-124.

14. Rycaj $\mathrm{K}$ and Tang DG. Cancer stem cells and radioresistance. International journal of radiation biology. 2014; 90:615-621.

15. Hittelman WN, Liao Y, Wang L and Milas L. Are cancer stem cells radioresistant? Future oncology (London, England). 2010; 6:1563-1576.

16. Jamal M, Rath BH, Tsang PS, Camphausen K and Tofilon PJ. The brain microenvironment preferentially enhances the radioresistance of CD133(+) glioblastoma stem-like cells. Neoplasia. 2012; 14:150-158.

17. Ropolo M, Daga A, Griffero F, Foresta M, Casartelli G, Zunino A, Poggi A, Cappelli E, Zona G, Spaziante R, Corte $\mathrm{G}$ and Frosina G. Comparative analysis of DNA repair in stem and nonstem glioma cell cultures. Molecular cancer research. 2009; 7:383-392.

18. Zhou W, Sun M, Li GH, Wu YZ, Wang Y, Jin F, Zhang YY, Yang L and Wang DL. Activation of the phosphorylation of ATM contributes to radioresistance of glioma stem cells. Oncology reports. 2013; 30:1793-1801.

19. van der Horst G, Bos L and van der Pluijm G. Epithelial plasticity, cancer stem cells, and the tumor-supportive stroma in bladder carcinoma. Molecular cancer research. 2012; 10:995-1009.

20. Chang L, Graham PH, Hao J, Ni J, Bucci J, Cozzi PJ, Kearsley JH and Li Y. PI3K/Akt/mTOR pathway inhibitors enhance radiosensitivity in radioresistant prostate cancer cells through inducing apoptosis, reducing autophagy, suppressing NHEJ and HR repair pathways. Cell death \& disease. 2014; 5:e1437.

21. Wang X, Ma Z, Xiao Z, Liu H, Dou Z, Feng X and Shi H. Chk1 knockdown confers radiosensitization in prostate cancer stem cells. Oncology reports. 2012; 28:2247-2254.

22. Wang M, Li X, Qu Y, Xu O and Sun Q. Hypoxia promotes radioresistance of CD133-positive Hep-2 human laryngeal squamous carcinoma cells in vitro. International journal of oncology. 2013; 43:131-140.

23. Piao LS, Hur W, Kim TK, Hong SW, Kim SW, Choi JE, Sung PS, Song MJ, Lee BC, Hwang D and Yoon SK. CD133+ liver cancer stem cells modulate radioresistance in human hepatocellular carcinoma. Cancer letters. 2012; 315:129-137.

24. Phillips TM, McBride WH and Pajonk F. The response of $\mathrm{CD} 24(-/$ low $/ \mathrm{CD} 44+$ breast cancer-initiating cells to radiation. Journal of the National Cancer Institute. 2006; 98:1777-1785.

25. Bao S, Wu Q, McLendon RE, Hao Y, Shi Q, Hjelmeland AB, Dewhirst MW, Bigner DD and Rich JN. Glioma stem cells promote radioresistance by preferential activation of the DNA damage response. Nature. 2006; 444:756-760.

26. Lim YC, Roberts TL, Day BW, Harding A, Kozlov S, Kijas AW, Ensbey KS, Walker DG and Lavin MF. A role for homologous recombination and abnormal cell-cycle 
progression in radioresistance of glioma-initiating cells. Molecular cancer therapeutics. 2012; 11:1863-1872.

27. Zhang M, Atkinson RL and Rosen JM. Selective targeting of radiation-resistant tumor-initiating cells. Proceedings of the National Academy of Sciences of the United States of America. 2010; 107:3522-3527.

28. Zhang M, Behbod F, Atkinson RL, Landis MD, Kittrell F, Edwards D, Medina D, Tsimelzon A, Hilsenbeck S, Green JE, Michalowska AM and Rosen JM. Identification of tumor-initiating cells in a p53-null mouse model of breast cancer. Cancer research. 2008; 68:4674-4682.

29. Xiao W, Graham PH, Power CA, Hao J, Kearsley JH and Li Y. CD44 is a biomarker associated with human prostate cancer radiation sensitivity. Clin Exp Metastasis. 2012; 29:1-9.

30. Sauer H, Wartenberg M and Hescheler J. Reactive oxygen species as intracellular messengers during cell growth and differentiation. Cellular physiology and biochemistry. 2001; 11:173-186.

31. Orrenius S. Reactive oxygen species in mitochondriamediated cell death. Drug metabolism reviews. 2007; 39:443-455.

32. DeNicola GM, Karreth FA, Humpton TJ, Gopinathan A, Wei C, Frese K, Mangal D, Yu KH, Yeo CJ, Calhoun ES, Scrimieri F, Winter JM, Hruban RH, IacobuzioDonahue C, Kern SE, Blair IA, et al. Oncogene-induced Nrf2 transcription promotes ROS detoxification and tumorigenesis. Nature. 2011; 475:106-109.

33. Dayem AA, Choi HY, Kim JH and Cho SG. Role of oxidative stress in stem, cancer, and cancer stem cells. Cancers. 2010; 2:859-884.

34. Dando I, Cordani M, Dalla Pozza E, Biondani G, Donadelli $\mathrm{M}$ and Palmieri M. Antioxidant Mechanisms and ROSRelated MicroRNAs in Cancer Stem Cells. Oxidative medicine and cellular longevity. 2015; 2015:425708.

35. Diehn M, Cho RW, Lobo NA, Kalisky T, Dorie MJ, Kulp AN, Qian D, Lam JS, Ailles LE, Wong M, Joshua B, Kaplan MJ, Wapnir I, Dirbas FM, Somlo G, Garberoglio $\mathrm{C}$, et al. Association of reactive oxygen species levels and radioresistance in cancer stem cells. Nature. 2009; 458:780783.

36. Blazek ER, Foutch JL and Maki G. Daoy medulloblastoma cells that express CD133 are radioresistant relative to CD133- cells, and the CD133+ sector is enlarged by hypoxia. International journal of radiation oncology, biology, physics. 2007; 67:1-5.

37. Kim YS, Kang MJ and Cho YM. Low production of reactive oxygen species and high DNA repair: mechanism of radioresistance of prostate cancer stem cells. Anticancer research. 2013; 33:4469-4474.

38. Lee YK, Hur W, Lee SW, Hong SW, Kim SW, Choi JE and Yoon SK. Knockdown of 14-3-3zeta enhances radiosensitivity and radio-induced apoptosis in CD133(+) liver cancer stem cells. Experimental \& molecular medicine.
2014; 46:e77.

39. Ke CC, Liu RS, Yang AH, Liu CS, Chi CW, Tseng LM, Tsai YF, Ho JH, Lee CH and Lee OK. CD133-expressing thyroid cancer cells are undifferentiated, radioresistant and survive radioiodide therapy. European journal of nuclear medicine and molecular imaging. 2013; 40:61-71.

40. Duru N, Fan M, Candas D, Menaa C, Liu HC, Nantajit D, Wen Y, Xiao K, Eldridge A, Chromy BA, Li S, Spitz DR, Lam KS, Wicha MS and Li JJ. HER2-associated radioresistance of breast cancer stem cells isolated from HER2-negative breast cancer cells. Clinical cancer research. 2012; 18:6634-6647.

41. Rami A. Review: Autophagy in neurodegeneration: firefighter and/or incendiarist? Neuropathology and Applied Neurobiology. 2009; 35:449-461.

42. Zhou S, Zhao L, Kuang M, Zhang B, Liang Z, Yi T, Wei $\mathrm{Y}$ and Zhao X. Autophagy in tumorigenesis and cancer therapy: Dr. Jekyll or Mr. Hyde? Cancer letters. 2012; 323:115-127.

43. Lomonaco SL, Finniss S, Xiang C, Decarvalho A, Umansky F, Kalkanis SN, Mikkelsen T and Brodie C. The induction of autophagy by gamma-radiation contributes to the radioresistance of glioma stem cells. International journal of cancer. 2009; 125:717-722.

44. Bao S, Wu Q, McLendon RE, Hao Y, Shi Q and Hjelmeland AB. Glioma stem cells promote radioresistance by preferential activation of the DNA damage response. Nature. 2006; 444:756-760.

45. Singh-Gupta V, Zhang H, Banerjee S, Kong D, Raffoul JJ, Sarkar FH and Hillman GG. Radiation-induced HIF-1alpha cell survival pathway is inhibited by soy isoflavones in prostate cancer cells. International journal of cancer. 2009; 124:1675-1684.

46. Ni J, Cozzi P, Hao J, Duan W, Graham P, Kearsley J and Li Y. Cancer stem cells in prostate cancer chemoresistance. Current cancer drug targets.2014; 14:225-240.

47. Datta K, Suman S and Fornace AJ, Jr. Radiation persistently promoted oxidative stress, activated mTOR via PI3K/Akt, and downregulated autophagy pathway in mouse intestine. The international journal of biochemistry \& cell biology. 2014; 57:167-176.

48. Zhu W, Fu $\mathrm{W}$ and $\mathrm{Hu}$ L. NVP-BEZ235, dual phosphatidylinositol 3-kinase/mammalian target of rapamycin inhibitor, prominently enhances radiosensitivity of prostate cancer cell line PC-3. Cancer biotherapy \& radiopharmaceuticals. 2013; 28:665-673.

49. Ni J, Cozzi P, Hao J, Beretov J, Chang L, Duan W, Shigdar S, Delprado W, Graham P, Bucci J, Kearsley J and Li Y. Epithelial cell adhesion molecule (EpCAM) is associated with prostate cancer metastasis and chemo/ radioresistance via the PI3K/Akt/mTOR signaling pathway. The international journal of biochemistry \& cell biology. 2013; 45:2736-2748.

50. Chen YH, Pan SL, Wang JC, Kuo SH, Cheng JC and Teng 
CM. Radiation-induced VEGF-C expression and endothelial cell proliferation in lung cancer. Strahlentherapie und Onkologie. 2014; 190:1154-1162.

51. Heavey S, O'Byrne KJ and Gately K. Strategies for cotargeting the PI3K/AKT/mTOR pathway in NSCLC. Cancer treatment reviews. 2014; 40:445-456.

52. Kim WY, Oh SH, Woo JK, Hong WK and Lee HY. Targeting heat shock protein 90 overrides the resistance of lung cancer cells by blocking radiation-induced stabilization of hypoxia-inducible factor-1alpha. Cancer research. 2009; 69:1624-1632.

53. Zhuang W, Qin Z and Liang Z. The role of autophagy in sensitizing malignant glioma cells to radiation therapy. Acta biochimica et biophysica Sinica. 2009; 41:341-351.

54. Liu T, Sun Q, Li Q, Yang H, Zhang Y, Wang R, Lin X, Xiao D, Yuan Y, Chen L and Wang W. Dual PI3K/mTOR inhibitors, GSK2126458 and PKI-587, suppress tumor progression and increase radiosensitivity in nasopharyngeal carcinoma. Molecular cancer therapeutics. 2015; 14:429439.

55. Chen YH, Wei MF, Wang CW, Lee HW, Pan SL, Gao M, Kuo SH, Cheng AL and Teng CM. Dual phosphoinositide 3-kinase/mammalian target of rapamycin inhibitor is an effective radiosensitizer for colorectal cancer. Cancer letters. 2015; 357:582-590.

56. Mehta M, Khan A, Danish S, Haffty BG and Sabaawy HE. Radiosensitization of Primary Human Glioblastoma Stem-like Cells with Low-Dose AKT Inhibition. Molecular cancer therapeutics. 2015; 14:1171-1180.

57. de la Cruz-Morcillo MA, Garcia-Cano J, Arias-Gonzalez L, Garcia-Gil E, Artacho-Cordon F, Rios-Arrabal S, Valero ML, Cimas FJ, Serrano-Oviedo L, Villas MV, RomeroFernandez J, Nunez MI and Sanchez-Prieto R. Abrogation of the p38 MAPK alpha signaling pathway does not promote radioresistance but its activity is required for 5-Fluorouracil-associated radiosensitivity. Cancer letters. 2013; 335:66-74.

58. Candas D, Lu CL, Fan M, Chuang FY, Sweeney C, Borowsky AD and Li JJ. Mitochondrial MKP1 is a target for therapy-resistant HER2-positive breast cancer cells. Cancer research. 2014; 74:7498-7509.

59. Liu H, Yang W, Gao H, Jiang T, Gu B, Dong Q, Xu W, $\mathrm{Wu} \mathrm{S}$ and Sun $\mathrm{X}$. Nimotuzumab abrogates acquired radioresistance of KYSE-150R esophageal cancer cells by inhibiting EGFR signaling and cellular DNA repair. OncoTargets and therapy. 2015; 8:509-518.

60. Xie Q, Zhou Y, Lan G, Yang L, Zheng W, Liang Y and Chen T. Sensitization of cancer cells to radiation by selenadiazole derivatives by regulation of ROS-mediated DNA damage and ERK and AKT pathways. Biochemical and biophysical research communications. 2014; 449:88-93.

61. Marampon F, Gravina GL, Zani BM, Popov VM, Fratticci A, Cerasani M, Di Genova D, Mancini M, Ciccarelli C, Ficorella C, Di Cesare E and Festuccia C. Hypoxia sustains glioblastoma radioresistance through ERKs/DNA-PKcs/ HIF-1alpha functional interplay. International journal of oncology. 2014; 44:2121-2131.

62. Huang EY, Chen YF, Chen YM, Lin IH, Wang CC, Su $\mathrm{WH}$, Chuang PC and Yang KD. A novel radioresistant mechanism of galectin-1 mediated by H-Ras-dependent pathways in cervical cancer cells. Cell death \& disease. 2012; 3:e251.

63. Marampon F, Gravina GL, Popov VM, Scarsella L, Festuccia C, La Verghetta ME, Parente S, Cerasani M, Bruera G, Ficorella C, Ricevuto E, Tombolini V, Di Cesare $\mathrm{E}$ and Zani BM. Close correlation between MEK/ERK and Aurora-B signaling pathways in sustaining tumorigenic potential and radioresistance of gynecological cancer cell lines. International journal of oncology. 2014; 44:285-294.

64. Drigotas M, Affolter A, Mann WJ and Brieger J. Reactive oxygen species activation of MAPK pathway results in VEGF upregulation as an undesired irradiation response. Journal of oral pathology \& medicine. 2013; 42:612-619.

65. Affolter A, Schmidtmann I, Mann WJ and Brieger J. Cancer-associated fibroblasts do not respond to combined irradiation and kinase inhibitor treatment. Oncology reports. 2013; 29:785-790.

66. Gupta AK, Bakanauskas VJ, Cerniglia GJ, Cheng Y, Bernhard EJ, Muschel RJ and McKenna WG. The Ras radiation resistance pathway. Cancer research. 2001; 61:4278-4282.

67. Seyfried T and Shelton L. Cancer as a metabolic disease. Nutrition \& Metabolism. 2010; 7:7.

68. Ciavardelli D, Rossi C, Barcaroli D, Volpe S, Consalvo A, Zucchelli M, De Cola A, Scavo E, Carollo R, D’Agostino D, Forli F, D’Aguanno S, Todaro M, Stassi G, Di Ilio $\mathrm{C}$, De Laurenzi V, et al. Breast cancer stem cells rely on fermentative glycolysis and are sensitive to 2-deoxyglucose treatment. Cell death \& disease. 2014; 5:e1336.

69. Vlashi E, Lagadec C, Vergnes L, Matsutani T, Masui K, Poulou M, Popescu R, Della Donna L, Evers P, Dekmezian C, Reue K, Christofk H, Mischel PS and Pajonk F. Metabolic state of glioma stem cells and nontumorigenic cells. Proceedings of the National Academy of Sciences of the United States of America. 2011; 108:16062-16067.

70. Shen YA, Lin CH, Chi WH, Wang CY, Hsieh YT, Wei YH and Chen YJ. Resveratrol Impedes the Stemness, EpithelialMesenchymal Transition, and Metabolic Reprogramming of Cancer Stem Cells in Nasopharyngeal Carcinoma through p53 Activation. Evidence-based complementary and alternative medicine 2013; 2013:590393.

71. Chen XH, Bao YY, Zhou SH, Wang QY, Wei Y and Fan J. Glucose transporter-1 expression in CD133+ laryngeal carcinoma Hep-2 cells. Molecular medicine reports. 2013; 8:1695-1700.

72. Bing Z, Yang G, Zhang Y, Wang F, Ye C, Sun J, Zhou G and Yang L. Proteomic analysis of effects by $\mathrm{x}$-rays and heavy ion in HeLa cells. Radiology and oncology. 2014; 
48:142-154

73. Shimura $T$, Noma N, Sano $Y$, Ochiai $Y$, Oikawa $T$, Fukumoto M and Kunugita N. AKT-mediated enhanced aerobic glycolysis causes acquired radioresistance by human tumor cells. Radiotherapy and oncology. 2014; 112:302-307.

74. Lynam-Lennon N, Maher SG, Maguire A, Phelan J, Muldoon C, Reynolds JV and O'Sullivan J. Altered mitochondrial function and energy metabolism is associated with a radioresistant phenotype in oesophageal adenocarcinoma. PloS one. 2014; 9:e100738.

75. Pitroda SP, Wakim BT, Sood RF, Beveridge MG, Beckett MA, MacDermed DM, Weichselbaum RR and Khodarev NN. STAT1-dependent expression of energy metabolic pathways links tumour growth and radioresistance to the Warburg effect. BMC medicine. 2009; 7:68.

76. Meng MB, Wang HH, Guo WH, Wu ZQ, Zeng XL, Zaorsky NG, Shi HS, Qian D, Niu ZM, Jiang B, Zhao LJ, Yuan ZY and Wang P. Targeting pyruvate kinase M2 contributes to radiosensitivity of non-small cell lung cancer cells in vitro and in vivo. Cancer letters. 2015; 356:985-993.

77. Giles FJ. The vascular endothelial growth factor (VEGF) signaling pathway: a therapeutic target in patients with hematologic malignancies. The oncologist. 2001; 6 Suppl 5:32-39.

78. Kunz M and Ibrahim SM. Molecular responses to hypoxia in tumor cells. Molecular cancer. 2003; 2:23.

79. Shi M, Guo XT, Shu MG, Chen FL and Li LW. Cellpermeable hypoxia-inducible factor-1 (HIF-1) antagonists function as tumor radiosensitizers. Medical hypotheses. 2007; 69:33-35.

80. Miyasaka A, Oda K, Ikeda Y, Sone K, Fukuda T, Inaba K, Makii C, Enomoto A, Hosoya N, Tanikawa M, Uehara Y, Arimoto T, Kuramoto H, Wada-Hiraike O, Miyagawa K, Yano T, et al. PI3K/mTOR pathway inhibition overcomes radioresistance via suppression of the HIF1-alpha/VEGF pathway in endometrial cancer. Gynecologic oncology. 2015 .

81. Tian S, Li XL, Shi M, Yao YQ, Li LW and Xin XY. Enhance tumor radiosensitivity by intracellular delivery of eukaryotic translation initiation factor $4 \mathrm{E}$ binding proteins. Medical hypotheses. 2011; 76:246-248.

82. Nojiri K, Iwakawa M, Ichikawa Y, Imadome K, Sakai M, Nakawatari M, Ishikawa K, Ishikawa A, Togo S, Tsujii $\mathrm{H}$, Shimada $\mathrm{H}$ and Imai $\mathrm{T}$. The proangiogenic factor ephrin-A1 is up-regulated in radioresistant murine tumor by irradiation. Experimental biology and medicine (Maywood, NJ). 2009; 234:112-122.

83. Affolter A, Fruth K, Brochhausen C, Schmidtmann I, Mann WJ and Brieger J. Activation of mitogen-activated protein kinase extracellular signal-related kinase in head and neck squamous cell carcinomas after irradiation as part of a rescue mechanism. Head \& neck. 2011; 33:1448-1457.

84. Takebe N, Miele L, Harris PJ, Jeong W, Bando H, Kahn
M, Yang SX and Ivy SP. Targeting Notch, Hedgehog, and Wnt pathways in cancer stem cells: clinical update. Nature reviews Clinical oncology. 2015; 12:445-464.

85. Weng AP, Ferrando AA, Lee W, Morris JPt, Silverman LB, Sanchez-Irizarry C, Blacklow SC, Look AT and Aster JC. Activating mutations of NOTCH1 in human T cell acute lymphoblastic leukemia. Science (New York, NY). 2004; 306:269-271.

86. Pece S, Serresi M, Santolini E, Capra M, Hulleman E, Galimberti V, Zurrida S, Maisonneuve P, Viale G and Di Fiore PP. Loss of negative regulation by Numb over Notch is relevant to human breast carcinogenesis. The Journal of cell biology. 2004; 167:215-221.

87. Kanamori M, Kawaguchi T, Nigro JM, Feuerstein BG, Berger MS, Miele L and Pieper RO. Contribution of Notch signaling activation to human glioblastoma multiforme. Journal of neurosurgery. 2007; 106:417-427.

88. Chiba S. Notch signaling in stem cell systems. Stem cells (Dayton, Ohio). 2006; 24:2437-2447.

89. Artavanis-Tsakonas S, Rand MD and Lake RJ. Notch signaling: cell fate control and signal integration in development. Science. 1999; 284:770-776.

90. Scharpfenecker M, Kruse JJ, Sprong D, Russell NS, Ten Dijke $P$ and Stewart FA. Ionizing radiation shifts the PAI$1 /$ ID-1 balance and activates notch signaling in endothelial cells. International journal of radiation oncology, biology, physics. 2009; 73:506-513.

91. Theys J, Yahyanejad S, Habets R, Span P, Dubois L, Paesmans K, Kattenbeld B, Cleutjens J, Groot AJ, Schuurbiers OC, Lambin P, Bussink J and Vooijs M. High NOTCH activity induces radiation resistance in non small cell lung cancer. Radiotherapy and oncology. 2013; 108:440-445.

92. Wang J, Wakeman TP, Lathia JD, Hjelmeland AB, Wang XF, White RR, Rich JN and Sullenger BA. Notch promotes radioresistance of glioma stem cells. Stem cells (Dayton, Ohio). 2010; 28:17-28.

93. Zhang X, Zheng L, Sun Y, Wang T and Wang B. Tangeretin enhances radiosensitivity and inhibits the radiation-induced epithelial-mesenchymal transition of gastric cancer cells. Oncology reports. 2015.

94. Kang J, Kim E, Kim W, Seong KM, Youn H, Kim JW, Kim $\mathrm{J}$ and Youn B. Rhamnetin and cirsiliol induce radiosensitization and inhibition of epithelial-mesenchymal transition (EMT) by miR-34a-mediated suppression of Notch-1 expression in non-small cell lung cancer cell lines. The Journal of biological chemistry. 2013; 288:2734327357.

95. Kyjacova L, Hubackova S, Krejcikova K, Strauss R, Hanzlikova H, Dzijak R, Imrichova T, Simova J, Reinis M, Bartek J and Hodny Z. Radiotherapy-induced plasticity of prostate cancer mobilizes stem-like non-adherent, Erk signaling-dependent cells. Cell death and differentiation. 2015; 22:898-911. 
96. Clevers $\mathrm{H}$ and Nusse R. Wnt/beta-catenin signaling and disease. Cell. 2012; 149:1192-1205.

97. Logan CY and Nusse R. The Wnt signaling pathway in development and disease. Annual review of cell and developmental biology. 2004; 20:781-810.

98. DiMeo TA, Anderson K, Phadke P, Fan C, Perou CM, Naber S and Kuperwasser C. A novel lung metastasis signature links Wnt signaling with cancer cell self-renewal and epithelial-mesenchymal transition in basal-like breast cancer. Cancer research. 2009; 69:5364-5373.

99. Chen MS, Woodward WA, Behbod F, Peddibhotla S, Alfaro MP, Buchholz TA and Rosen JM. Wnt/beta-catenin mediates radiation resistance of Sca1+ progenitors in an immortalized mammary gland cell line. Journal of cell science. 2007; 120:468-477.

100. Su H, Jin X, Zhang X, Xue S, Deng X, Shen L, Fang Y and $\mathrm{Xie} \mathrm{C}$. Identification of microRNAs involved in the radioresistance of esophageal cancer cells. Cell biology international. 2014; 38:318-325.

101. Su H, Jin X, Zhang X, Zhao L, Lin B, Li L, Fei Z, Shen L, Fang Y, Pan H and Xie C. FH535 increases the radiosensitivity and reverses epithelial-to-mesenchymal transition of radioresistant esophageal cancer cell line KYSE-150R. Journal of translational medicine. 2015; 13:104.

102. Bastos LG, de Marcondes PG, de-Freitas-Junior JC, Leve F, Mencalha AL, de Souza WF, de Araujo WM, Tanaka MN, Abdelhay ES and Morgado-Diaz JA. Progeny from irradiated colorectal cancer cells acquire an EMT-like phenotype and activate Wnt/beta-catenin pathway. Journal of cellular biochemistry. 2014; 115:2175-2187.

103. Cojoc M, Peitzsch C, Kurth I, Trautmann F, KunzSchughart LA, Telegeev GD, Stakhovsky EA, Walker JR, Simin K, Lyle S, Fuessel S, Erdmann K, Wirth MP, Krause M, Baumann M and Dubrovska A. Aldehyde Dehydrogenase Is Regulated by beta-Catenin/TCF and Promotes Radioresistance in Prostate Cancer Progenitor Cells. Cancer research. 2015; 75:1482-1494.

104. Zhang H, Luo H, Hu Z, Peng J, Jiang Z, Song T, Wu B, Yue J, Zhou R, Xie R, Chen T and Wu S. Targeting WISP1 to sensitize esophageal squamous cell carcinoma to irradiation. Oncotarget. 2015; 6:6218-6234. doi: 10.18632/ oncotarget.3358.

105. Lin TY, Chang JT, Wang HM, Chan SH, Chiu CC, Lin CY, Fan KH, Liao CT, Chen IH, Liu TZ, Li HF and Cheng AJ. Proteomics of the radioresistant phenotype in headand-neck cancer: Gp96 as a novel prediction marker and sensitizing target for radiotherapy. International journal of radiation oncology, biology, physics. 2010; 78:246-256.

106. Sattler UG, Meyer SS, Quennet V, Hoerner C, Knoerzer H, Fabian C, Yaromina A, Zips D, Walenta S, Baumann $\mathrm{M}$ and Mueller-Klieser W. Glycolytic metabolism and tumour response to fractionated irradiation. Radiotherapy and oncology. 2010; 94:102-109.
107. Koukourakis MI, Giatromanolaki A, Panteliadou M, Pouliliou SE, Chondrou PS, Mavropoulou S and Sivridis E. Lactate dehydrogenase 5 isoenzyme overexpression defines resistance of prostate cancer to radiotherapy. British journal of cancer. 2014; 110:2217-2223. 